\title{
D-AMPHETAMINE TOXICITY IN FRESHLY ISOLATED RAT HEPATOCYTES: A POSSIBLE ROLE OF CYP3A
}

\author{
Vessela VITCHEVA, Magdalena KONDEVA-BURDINA, and Mitka MITCHEVA \\ Laboratory of Drug Metabolism and Drug Toxicity, Department of Pharmacology, Pharmacotherapy, \\ and Toxicology, Faculty of Pharmacy, Medical University Sofia, Sofia, Bulgaria
}

Received in September 2008

Accepted in December 2008

\begin{abstract}
The aim of this study was to trace D-amphetamine toxicity in isolated rat hepatocytes and to elucidate a possible involvement of CYP3A in the mechanisms of its toxicity. To this end, male Wistar rats were treated with nifedipine ( $5 \mathrm{mg} \mathrm{kg}^{-1}$ i.p., 5 days), a substrate and inducer of CYP3A. Hepatocytes isolated from nifedipine-treated and control rats were incubated with D-amphetamine at a concentration of $100 \mu \mathrm{mol} \mathrm{L}^{-1}$, which was determined to be an average toxic concentration $\left(\mathrm{TC}_{50}\right)$ for the compound. To evaluate the possible toxic effects of D-amphetamine on freshly isolated rat hepatocytes, we assessed the following parameters: cell viability, lactate dehydrogenase (LDH) activity, and glutathione (GSH).

The results showed that nifedipine potentiated amphetamine cytotoxicity in vitro, as follows: cell viability dropped by $65 \%(p<0.001)$, GSH by $80 \%(p<0.001)$, and LDH activity increased by $190 \%(p<0.001)$. To clarify the role of nifedipine in amphetamine cytotoxicity, we used amiodarone, a substrate and an inhibitor of CYP3A. Pre-incubation of nifedipine-treated hepatocytes with amiodarone $\left(14 \mu \mathrm{mol} \mathrm{L}^{-1}\right)$ significantly lowered amphetamine cytotoxicity.

Our results confirmed the toxicity of D-amphetamine in isolated rat hepatocytes and the involvement of CYP3A in its metabolism and hepatotoxicity.
\end{abstract}

KEY WORDS: amiodarone, amphetamine cytotoxicity, nifedipine

Amphetamines are potent psychostimulants and commonly used drugs of abuse. Not only does chronic amphetamine administration create tolerance and addiction, but is also associated with neurotoxicity and hepatocellular damage through oxidative stress. Amphetamine is a drug of abuse with variable interspecies biotransformation (1). In rats its aromatic ring is hydroxylated, and the urinary excretion of $\mathrm{p}$ hydroxyamphetamine $(81 \%)$ is the main elimination pathway (1). Animal studies in vitro (2) and in vivo (3) have proved that $\mathrm{D}$-amphetamine 4-hydroxylation in rats is favoured by CYP2D. This metabolic pathway is thought to be responsible for amphetamine hepatotoxicity. Experimental studies performed in isolated rat hepatocytes by Carvalho et al. (4) have proved that in the liver D-amphetamine metabolises into an epoxide, its toxic intermediate, which reacts with glutathione, and forms a GSH-adduct (GSHS-yl-p-hydroxyamphetamine). This partly explains $\mathrm{D}$-amphetamine hepatotoxicity. D-amphetamine is a substrate of CYP2D, but it is also known to inhibit cytochrome $\mathrm{P} 450$ through a nitroso metabolic intermediate, which complexes with the enzyme and causes its inhibition and possible toxic effects $(5,6)$. The main cytochrome $\mathrm{P} 450$ isoform which catalyses the formation of the nitroso intermediate is CYP3A (7).

This suggests a possible involvement of other cytochrome P450 isoenzymes in D-amphetamine metabolism and hepatotoxicity, and the objective of 
this study was to elucidate a possible involvement of CYP3A in D-amphetamine hepatotoxicity in isolated rat hepatocytes.

\section{MATERIALS AND METHODS}

\section{Animals}

Male Wistar rats (body weight $200 \mathrm{~g}$ to 250 g) were housed in Plexiglas cages ( 3 per cage) at $(20 \pm 2)^{\circ} \mathrm{C}$ and 12-h light : 12-h dark cycle. Food and water were provided ad libitum. The animals were purchased from the National Breeding Centre, Sofia, Bulgaria. All procedures were approved by the Institutional Animal Care Committee and performed strictly following the principles stated in the European Convention for the Protection of Vertebrate Animals used for Experimental and other Scientific Purposes (ETS 123) (1991) (8).

\section{Experimental design}

The animals were divided in two groups $(\mathrm{n}=6)$ : the control group treated intraperitoneally (i.p.) with saline $0.9 \%$ twice a day for 5 days, and a group receiving intraperitonally $5 \mathrm{mg} \mathrm{kg}^{-1}$ of nifedipine, an inducer of CYP 3A, twice a day for 5 days. This nifedipine dose was based on previous experiments in which we found that multiple nifedipine administration to rats $\left(5 \mathrm{mg} \mathrm{kg}^{-1}\right.$, i.p., twice daily for 5 days) led to an increase in cytochrome P450 (9).

\section{Chemicals and reagents}

All reagents used were of analytical grade. The drugs used in this study, D-amphetamine sulphate, nifedipine, and amiodarone, as well as other chemicals, collagenase (type IV), bovine serum albumin (fraction V), 4-(2-hydroxyethyl)-1-piper-azineethanesulphonic acid (HEPES), glutathione (GSH), and [ethylenebis (oxyethylenenitrilo)] tetraacetic acid (EGTA) were purchased form Sigma Chemical Co. (Germany). 2,2'-dinitro-5,5'dithiodibenzoic acid (DTNB) was obtained from MERCK (Germany) and the Lactate Dehydrogenase Kit (EC 1.1.1.27) was obtained from Randox (United Kingdom).

\section{Isolation of hepatocytes}

Rats were anesthetised with sodium pentobarbutal ( $0.2 \mathrm{~mL}$ per $100 \mathrm{~g} \mathrm{~b}$. w.).Two-stepped collagenase liver perfusion and cell isolation were performed in situ, as described by Fau (10) with modifications (11). After portal catheterisation, the liver was perfused with $100 \mathrm{~mL}$ of HEPES buffer $(\mathrm{pH}=7.85)$ containing $10 \mathrm{mmol} \mathrm{L}^{-1} \mathrm{HEPES}, 142 \mathrm{mmol} \mathrm{L}^{-1} \mathrm{NaCl}$, $7 \mathrm{mmol} \mathrm{L}{ }^{-1} \mathrm{KCl}, 5 \mathrm{mmol} \mathrm{L}^{-1}$ glucose, and $0.6 \mathrm{mmol} \mathrm{L}^{-1}$ EDTA ( $\mathrm{pH}=7.85$ ), then by $200 \mathrm{~mL}$ of HEPES buffer $(\mathrm{pH}=7.85)$ alone, and finally by $200 \mathrm{~mL}$ of HEPES buffer containing collagenase type IV $(50 \mathrm{mg}$ per $200 \mathrm{~mL}$ ) and $7 \mathrm{mmol} \mathrm{L}^{-1} \mathrm{CaCl}_{2}(\mathrm{pH}=7.85)$. The liver was removed, minced, and hepatocytes were dispersed in $60 \mathrm{~mL}$ Krebs-Ringer-bicarbonate (KRB) buffer $(\mathrm{pH}=7.35)$, containing $1.2 \mathrm{mmol} \mathrm{L}^{-1} \mathrm{KH}_{2} \mathrm{PO}_{4}$, $1 \mathrm{mmol} \mathrm{L}^{-1} \mathrm{CaCl}_{2}, 1.2 \mathrm{mmol} \mathrm{L}^{-1} \mathrm{MgSO}_{4}, 5 \mathrm{mmol} \mathrm{L}^{-1}$ $\mathrm{KCl}, 5 \mathrm{mmol} \mathrm{L}^{-1} \mathrm{NaHCO}_{3}, 4.5 \mathrm{mmol} \mathrm{L}^{-1}$ glucose, and $1 \%$ bovine serum albumin. After filtration, the hepatocytes were centrifuged at 500xg for $1 \mathrm{~min}$ and washed three times with the KRB buffer. The initial viability, assessed using the Trypan blue exclusion method (10), averaged $90 \%$. Cells were then diluted with KRB to make a suspension of approximately $3 \times 10^{6}$ hepatocytes per $\mathrm{mL}$ and incubated in sterile $25 \mathrm{~mL}$ Erlenmeyer flasks, each containing $3 \mathrm{~mL}$ of the cell suspension (i.e. $9 \times 10^{6}$ hepatocytes).

\section{Incubation of hepatocytes}

In order to choose appropriate amphetamine concentration for the in vitro experiments, hepatocytes were incubated with D-amphetamine at four concentrations $\left(50 \mu \mathrm{mol} \mathrm{L}^{-1}, 100 \mu \mathrm{mol}\right.$ $\mathrm{L}^{-1}, 150 \mu \mathrm{mol} \mathrm{L}^{-1}$, and $200 \mu \mathrm{mol} \mathrm{L}^{-1}$ ) for one hour. Average toxic amphetamine concentration $\left(\mathrm{TC}_{50}\right)$ was determined (Figure 1) to be $100 \mu \mathrm{mol} \mathrm{L}^{-1}$ $\left(\mathrm{TC}_{50}=1.05 \times 10^{-4} \mathrm{~mol} \mathrm{~L}^{-1}\right)$. Hepatocytes isolated from the animals of both groups were incubated with $\mathrm{D}$-amphetamine at $\mathrm{TC}_{50}$ for one hour. Hepatocytes isolated from nifedipine-treated rats were pre-

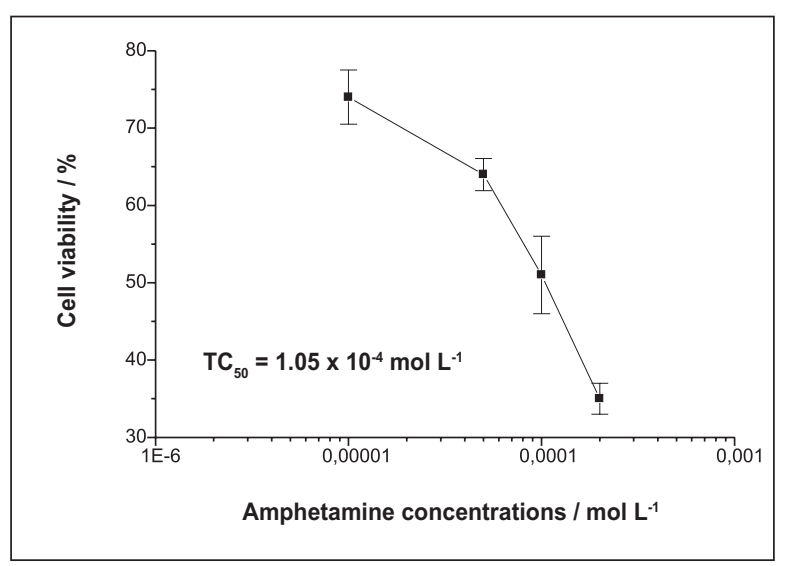

Figure 1 The influence of D-amphetamine on cell viability in rat hepatocytes 
incubated for 15 min with amiodarone $\left(14 \mu \mathrm{mol} \mathrm{L}^{-1}\right)$ (12) and then incubated for with D-amphetamine for one hour. Incubations were performed in a $5 \% \mathrm{CO}_{2}+$ $95 \% \mathrm{O}_{2}$ atmosphere (10). For both groups, non-treated hepatocytes were used as controls.

The following parameters were used to evaluate amphetamine cytotoxicity: cell viability, LDH activity, and GSH level. Cell viability was assessed using the Trypan blue exclusion method (10). The dye was used at the final concentration of $0.05 \%$, and approx. 300 cells were counted under a light microscope (x100). Cell samples were taken from each experimental group from three separate hepatocyte preparations at hour one of incubation. At the end of incubation, cells were recovered by centrifugation at $400 \mathrm{xg}$ at $4{ }^{\circ} \mathrm{C}$. The supernatant was used for the assessment of LDH activity while the sediment to measure intracellular glutathione (GSH). The level of LDH activity was measured spectrophotometrically, as described by Bergmeyer et al. (13), using a commercially available kit (LDH opt., Randox). Briefly, the method is based on the reduction of pyruvate to lactate. During the reduction, an equimolar amount of NADH is oxidised to $\mathrm{NAD}^{+}$, which leads to a decrease in the absorbance at $340 \mathrm{~nm}$, measured at minute 1 , 2 , and 3. The decrease in absorbance at $340 \mathrm{~nm}$ is directly proportional to LDH activity in the sample. LDH activity was calculated from the absorbance of $\mathrm{NADH}(6.22 \mathrm{mmol})$, and the final results are given in mmol L-1 $\mathrm{min}^{-1}$ per $10^{6}$ cells.

The GSH level was assessed by measuring nonprotein sulfhydryls after precipitation of proteins with trichloroacetic acid (TCA), followed by measurement of thiols in the supernatant using 2,2'-dinitro- 5,5'-dithiodibenzoic acid (DTNB) as reagent. The absorbance was measured at $412 \mathrm{~nm}$ (10), using a Spectro UV-VIS Split spectrophotometer, and the final results are expressed in nmol per $10^{6}$ cells.

\section{Statistical analysis}

Statistical analysis included ANOVA and the Student's $t$-test. Probability values of less than 0.05 were considered significant. The results were presented as means $\pm \mathrm{SD}$ of four animals per group. For each of the examined parameters, three parallel samples were used.

\section{RESULTS}

After one-hour of incubation in vitro, cell viability showed a slight, non-significant decrease from the initial value ( $\sim 90 \%)$ to $85 \%$ in the hepatocytes isolated from non-treated rats and to $78 \%$ in the hepatocytes isolated from nifedipine-treated rats (Table 1). D-amphetamine administered in vitro at a concentration of $100 \mu \mathrm{mol} \mathrm{L}^{-1}$ affected cell viability, LDH activity, and GSH levels in hepatocytes isolated from non-treated and Nifedipine-treated rats. The incubation of hepatocytes isolated from non-treated rats with $\mathrm{D}$-amphetamine led to a decrease in cell viability by $40 \%(\mathrm{p}<0.05)$, increased LDH leakage by $184 \%(\mathrm{p}<0.05)$, and decreased level of cellular GSH by $54 \%(p<0.05)$. Nifedipine treatment potentiated D-amphetamine cytotoxicity, and the most affected parameter was GSH level, followed by cell viability, and LDH activity. GSH was depleted by $80 \%$

Table 1 The effect of D-amphetamine (100 $\left.\mu \mathrm{mol} \mathrm{L}^{-1}\right)$ administered in vitro on cell viability, LDH activity, and GSH level in hepatocytes isolated from non-treated and nifedipine-treated rats

\begin{tabular}{|c|c|c|c|}
\hline Sample & $\begin{array}{c}\text { Cell } \\
\text { viability / } \\
\% \\
\end{array}$ & $\begin{array}{l}\text { LDH activity } \\
\text { per } 10^{6} \text { cells / } \\
\text { mmol L-1 } \text { min }^{-1}\end{array}$ & $\begin{array}{c}\text { GSH level } \\
\text { per } 10^{6} \text { cells / } \\
\text { nmol }\end{array}$ \\
\hline \multicolumn{4}{|l|}{ Non-treated rats } \\
\hline Control hepatocytes & $85 \pm 3.2$ & $0.131 \pm 0.01$ & $19.14 \pm 1.93$ \\
\hline Hepatocytes exposed in vitro to D-amphetamine & $51 \pm 2.0^{*}$ & $0.372 \pm 0.07 *$ & $8.85 \pm 0.10 *$ \\
\hline \multicolumn{4}{|l|}{ Nifedipine-treated rats } \\
\hline Control hepatocytes & $78 \pm 5.1$ & $0.165 \pm 0.03$ & $17.00 \pm 2.67$ \\
\hline Hepatocytes exposed in vitro to D-amphetamine & $26 \pm 1.5^{+\#}$ & $0.479 \pm 0.03^{+*}$ & $3.40 \pm 0.40^{+\#}$ \\
\hline
\end{tabular}

Note. Data are expressed as mean $\pm S D$ of four different experiments.

${ }^{*} p<0.05$ vs. LDH activity hepatocytes from non-treated rats

${ }^{+} p<0.05$ vs. per $10^{6}$ cells / hepatocytes from nifedipine-treated rats

$\# p<0.05$ vs. mmol $L^{-1} \mathrm{~min}^{-1}$ hepatocytes from non-treated rats exposed to D-amphetamine 
$(\mathrm{p}<0.05)$ which is $62 \%(\mathrm{p}<0.05)$ more than the effect of D-amphetamine on hepatocytes isolated from nontreated rats. Cell viability decreased by $67 \%(\mathrm{p}<0.05)$, which is $51 \%(\mathrm{p}<0.05)$ more than it was observed in amphetamine-treated hepatocytes isolated from non-treated rats. LDH activity increased by $190 \%$ $(p<0.05)$, which is commeasurable with the effect of amphetamine on cells isolated from non-treated rats.

Table 2 shows the influence of amiodarone $(14 \mu \mathrm{mol} \mathrm{L}-1)$ on D-amphetamine effects in hepatocytes isolated from nifedipine-treated rats. Amiodarone itself exerted a hepatotoxic effect, manifested by a decrease in cell viability and GSH level by $35 \%$ $(\mathrm{p}<0.05)$ and $50 \%(\mathrm{p}<0.05)$, respectively, and by an increase in LDH activity by $101 \%(p<0.05)$. Preincubation of hepatocytes with amiodarone resulted in lower cytotoxycity of D-amphetamine. Cell viability and the GSH level increased $22 \%(\mathrm{p}<0.05)$ and $79 \%$ $(\mathrm{p}<0.05)$, respectively, while LDH activity decreased $45 \%(p<0.05)$ in respect to hepatocytes treated with D-amphetamine alone.

\section{DISCUSSION}

Amphetamines belong to a class of drugs known as central nervous system indirect-acting sympathomymetics, which are commonly abused due to their physical and psychostimulating effects. Sympathetic arousal induced by amphetamine produces rapid and sometimes irregular heart rate, sweating, papillary dilation, hypertension, and increased body temperature. The psychological changes include euphoria, alertness, hypervigilance, and decreased appetite. Beside the risk of developing tolerance and addiction, chronic abusers may experience neurotoxic effects (14) and hepatocellular damage (15). The latter has increasingly been reported in humans $(16,17)$.

In vitro studies in rats (4) have shown that amphetamine hepatotoxicity is closely related to its bioactivation and GSH-adduct (GSH-S-ylp-hydroxyamphetamine) formation, a process considered to be catalysed by CYP2D (4). Although the p-hydroxylation of amphetamine is considered to be the main metabolic pathway (1), it is possible that some other cytochrome P 450 dependent metabolic pathways be involved in its toxicity. There are clinical data revealing significant interactions between recreational drugs, including amphetamine, and potent inhibitors of CYP3A4 such as some of the HIV protease inhibitors (18). Antiretroviral may cause fatal amphetamine accumulation from normally safe dosages, as they inhibit amphetamine metabolism. It is therefore possible that CYP3A was involved in amphetamine metabolism and toxicity in rats.

L-type calcium channel blockers of the dihydropiridine class, such as nifedipine, nimodipine, and amlodipine have been reported to affect addiction to various types of drugs, including psychostimulants (19). At the same time, they are substrates of one of cytochrome $\mathrm{P} 450$ most abundant isoenzyme CYP3A. Nifedipine is known to induce cytochrome $\mathrm{P} 450$ both in rats (20) and humans (21).

To test the hypothesis of a possible involvement of CYP3A in amphetamine toxicity we used rat hepatocytes isolated from non-treated and nifedipine-

Table 2 The influence of amiodarone $\left(14 \mu \mathrm{mol} \mathrm{L}^{-1}\right)$ on the toxic effects of D-amphetamine in hepatocytes isolated from nifedipinetreated rats

\begin{tabular}{lccc}
\hline Sample & $\begin{array}{c}\text { Cell } \\
\text { Viability / } \\
\text { \% }\end{array}$ & $\begin{array}{c}\text { LDH activity } \\
\text { per 10 } \\
\text { mmol L }^{-1} \mathbf{~ m i n}^{-1}\end{array}$ & $\begin{array}{c}\text { GSH level } \\
\text { per 10 } \\
\text { nmol }\end{array}$ \\
\hline $\begin{array}{l}\text { Control } / \\
\text { rats }\end{array}$ & $78 \pm 5.0$ & $0.165 \pm 0.01$ & $17.00 \pm 1.7$ \\
\hline $\begin{array}{l}\text { Hepatocytes exposed } \text { in vitro to amiodarone } \\
\left(14 \mu \mathrm{mol} \mathrm{L}^{-1}\right)\end{array}$ & $51 \pm 7.0^{*}$ & $0.334 \pm 0.03^{*}$ & $8.42 \pm 1.3^{*}$ \\
\hline $\begin{array}{l}\text { Hepatocytes exposed } \text { in vitro to D-amphetamine } \\
\left(100 \mu \mathrm{mol} \mathrm{L}^{-1}\right)\end{array}$ & $36 \pm 2.0^{*}$ & $0.479 \pm 0.03^{*}$ & $4.50 \pm 0.4^{*}$ \\
\hline $\begin{array}{l}\text { Hepatocytes exposed } \text { in vitro to D-amphetamine and } \\
\text { amiodarone }\end{array}$ & $44 \pm 1.5^{*+}$ & $0.225 \pm 0.04^{+}$ & $8.05 \pm 1.5^{*+}$ \\
\hline
\end{tabular}

Note. Data are expressed as mean $\pm S D$ of four experiments

${ }^{*} p<0.05$ vs. control

${ }^{+} p<0.05$ vs. hepatocytes treated only with D-amphetamine 
treated rats, which were then incubated with amphetamine. Our results showed that nifedipine increased amphetamine cytotoxicity.

Cell GSH was the most affected (Table 1) and its significant depletion is an interesting finding. It seems that CYP2D favours the formation of $p$ hydroxyamphetamine, and CYP2D is known not to be inducible (22). The observed decrease in the hepatocyte GSH level caused by amphetamine in nifedipine-treated rats may therefore be a result of nifedipine induction of CYP3A. In addition, multiple nifedipine administration may induce several other CYP isoforms such as CYP2B and CYP2C (23). Literature data suggest that in addition to CYP2D, aromatic hydroxylation is catalysed by CYP2B (24), which can be induced by nifedipine, and therefore also responsible for the GSH depletion. This hypothesis, however, needs further investigations that are an object of future studies.

In order to clarify the role of nifedipine in amphetamine toxicity, hepatocytes isolated from nifedipine-treated rats were pretreated with amiodarone, a substrate and inhibitor of CYP3A (23; 12). At a concentration of $14 \mu \mathrm{mol} \mathrm{L}^{-1}$ amiodarone decreased cell viability and $\mathrm{GSH}$, and increased LDH activity (Table 2). Pre-incubation of hepatocytes with amiodarone significantly reduced $\mathrm{D}$-amphetamine cytotoxicity. The most indicative was the effect on the GSH level (Table 2). These results suggest that amiodarone may interfere with amphetamine metabolism by inhibiting amphetamine's toxic metabolites to form. However, because amiodarone is metabolised by CYP3A, a competition between the two compounds is likely. To better understand this interaction, a more specific inhibitor should be used, such as ketoconazole.

Using an inducer and inhibitor of CYP3A proved to be a reliable approach in elucidating the involvement of this isoform in amphetamine hepatotoxicity in isolated rat hepatocytes.

\section{REFERENCES}

1. Caldwell J. The metabolism of amphetamines and related stimulants in animals and man. In: Caldwell J, editor Amphetamines and related stimulants: Chemical biological and sociological aspects. Boca Raton: CRC Press Inc.; 1980. p. 29-46.

2. Bach MV, Coutts RT, Baker GB. Involvement of CYP2D6 in the in vitro metabolism of amphetamine, two $\mathrm{N}$ alkylamphetamines and their 4-methoxylated derivatives. Xenobiotica 1999;29:719-32.
3. Law MY, Slawson MH, Moody DE. Selective involvement of cytochrome P450 2D subfamily in in vivo 4-hydroxylation of amphetamine in rat. Drug Metab Dispos 2000;28:348-53.

4. Carvalho F, Remião F, Amado F, Domingues P, Correia AJ, Bastos ML. D-Amphetamine interaction with glutathione in freshly isolated rat hepatocytes. Chem Res Toxicol 1996;9:1031-6.

5. Yanada H, Oguri K, Yoshimura H. Effects of several factors on urinary excretion of methamphetamine and its metabolites in rats. Xenobiotica 1986;16:137-41.

6. Timbrell J. 2000. Factors affecting metabolism and disposition-Enzyme inhibition. In: Principles of Biochemical Toxicology. $3^{\text {rd }}$ ed. New York (NY): Taylor and Francis; 2000. p. 164-5.

7. Graham RJ, Benet LZ. Antiprogestin-mediated inactivation of cytochrome P 450 CYP 3A4. Int J Exp Clin Pharmacol 1998;56:150-7.

8. Council of Europe. European Convention for the Protection of Vertebrate Animals used for Experimental and other Scientific Purposes. CETS No. 123, 1991 [displayed 30 May 2007] Available at http://conventions.coe.int/treaty/ Commun/QueVoulezVous.asp?NT=123ECL=ENG.

9. Vitcheva V, Mitcheva M. Effect of nifedipine on behavioral and biochemical parameters in rats after multiple morphine administration. Methods Find Exp Clin Pharmacol 2004;26:631-4.

10. Fau D, Berson A, Eugene D, Formently B, Fisch C, Pessayre D. Mechanism for the hepatotoxicity of the antiandrogen Nilutamide. Evidence suggesting that redox cycling of this nitroaromatic drug lead to oxidative stress in isolated hepatocytes. J Pharm Exp Ther 1992;263:69-77.

11. Mitcheva M, Kondeva M, Vitcheva V, Nedialkov P, Kitanov G. Effect of benzophenones from Hypericum annulatum on carbon tetrachloride-induced toxicity in freshly isolated rat hepatocytes. Redox Rep 2006;11:3-8.

12. Ohyama K, Nakajiama M, Suzuki M, Shimada N, Yamazaki H, Yoki T. Inhibitory effects of amiodarone and its N-deethylated metabolite on human cytochrome P 450 activities: prediction of in vivo drug interactions. Br J Clin Pharmacol 2000;49:244-53.

13. Bergmeyer HU, editor. Methods of enzymatic analysis. Vol 1. New York (NY) / London: Verlag Chemie - Academic Press; 1974.

14. Advokat C. Update on amphetamine neurotoxicity and its relevance to the treatment of ADHD. J Atten Disord 2007;11:8-16.

15. Carvalho F, Remião F, Soares ME, Catarino R, Queiroz G, Bastos ML. D-Amphetamine-induced hepatotoxicity: possible contribution of catecholamines and hyperthermia to the effects studied in isolated hepatocytes. Arch Toxicol 1997;71:429-36.

16. Jones AJ, Simpson KJ. Review article: mechanisms and management of hepatotoxicity in ecstasy (MDMA) and amphetamine intoxications. Aliment Pharmacol Ther 1999;13:129-33.

17. Maurer HH, Kraemer T, Springer D, Staack RF. Chemistry, pharmacology, toxicology, and hepatic metabolism of designer drugs of the amphetamine (ecstasy), piperazine, and pyrrolidinophenone types: a synopsis. Ther Drug Monit 2004:26:127-31.

18. Antoniou T, Tseng AL. Interactions between recreational drugs and antiretroviral agents. Ann Pharmacother 2002:36:1598-613. 
19. Shulman A, Jagoda J, Laycock G, Kelly H. Calcium channel blocking drugs in the management of drug dependence, withdrawal and craving. A clinical pilot study with nifedipine and verapamil. Aust Fam Physician 1998;27(Suppl 1):S1924.

20. Kastelova A, Koleva M, Staneva-Stoytcheva D. Changes in rat liver monooxygenase activities after administration of atenolol, nifedipine and diltiazem alone and in combination. Methods Find Exp Clin Pharmacol 2000;22:627-31.

21. Drocourt L, Pascussi JM, Assenat E, Fabre JM, Maurel P, Vilarem MJ. Calcium channel modulators of the dihydropyridine family are human pregnane $\mathrm{X}$ receptor activators and inducers of CYP $3 \mathrm{~A}, \mathrm{CYP} 2 \mathrm{~B}$ and $\mathrm{CYP} 2 \mathrm{C}$ in human hepatocytes. Drug Metab Dispos 2001;29:1325-31.

22. Diehl KH, Hull R, Morton D, Pfizer R, Rabemampianina Y, Smith D, Vidal JM, van de Vorstenbosch C. A good practice guide to the administration of substances and removal of blood, including routs and volumes. J Appl Toxicol 2001;21:15-23.

23. Coleman MD. Human Drug Metabolism. West Sussex: John Wiley and Sons; 2006.

24. Ha HR, Bigler L, Binder M, Korlik P, Stieger B, Heese M, Altorfer HR, Follath F. Metabolism of amiodarone (part I): identification of a new hydroxylated metabolite of amiodarone. Drug Metab Dispos 2001;29:152-8. 
Sažetak

\section{ULOGA CYP3A-ENZIMA U TOKSIČNOSTI D-AMFETAMINA U SVJEŽE IZOLIRANIMA ŠTAKORSKIM HEPATOCITIMA}

Cilj je ovoga istraživanja bio utvrditi toksičnost D-amfetamina u izoliranim štakorskim hepatocitima kako bi se razjasnila eventualna uloga enzima CYP3A u mehanizmu toksičnosti ovoga lijeka. U tu su svrhu mužjaci Wistar štakora pet dana primali nifedipin $\left(5 \mathrm{mg} \mathrm{kg}^{-1} i p\right.$. $)$, koji je supstrat i induktor CYP3A. Stanice izolirane iz jetre štakora koji su primali nifedipin i kontrolnih štakora inkubirane su s D-amfetaminom u njegovoj srednjoj toksičnoj koncentraciji $\left(\mathrm{TC}_{50}\right)$ od $100 \mu \mathrm{mol} \mathrm{L}^{-1}$. Za procjenu eventualnoga toksičnoga djelovanja D-amfetamina na svježe izolirane hepatocite uporabili smo sljedeće parametre: preživljenje stanica te razine laktat dehidrogenaze (LDH) i glutationa (GSH). Rezultati su pokazali da je nifedipin pojačao toksično djelovanje amfetamina in vitro na sljedeći način: preživljenje stanica palo je za $65 \%$ $(\mathrm{p}<0,001)$, GSH za $80 \%(\mathrm{p}<0,001)$, a razine LDH porasle su za $190 \%(\mathrm{p}<0.001)$. Radi pojašnjenja uloge nifedipina u citotoksičnosti amfetamina uporabili smo amiodaron, koji je supstrat i inhibitor CYP3A. Inkubacija hepatocita štakora koji su primali nifedipin s amiodaronom $\left(14 \mu \mathrm{mol} \mathrm{L}^{-1}\right)$ prije dodavanja amfetamina značajno je smanjila njegovu citotoksičnost. Ovi rezultati potvrđuju da D-amfetamin djeluje toksično na štakorske hepatocite te da u njegovome metabolizmu i toksičnome djelovanju na jetru sudjeluje CYP3A.

KLJUČNE RIJEČI: amfetamin, amiodaron, citotoksičnost, nifedipin

\section{CORRESPONDING AUTHOR:}

Vessela Vitcheva

Faculty of Pharmacy,

Department of Pharmacology and Toxicology

Ulitza Dunav № 2, 1000 Sofia, Bulgaria

E-mail: vesselavitcheva@yahoo.com 